\title{
ANALISIS MOTIVASI BELAJAR SISWA DALAM PEMBELAJARAN FISIKA SEKOLAH MENENGAH ATAS
}

\section{THE ANALYSIS OF STUDENTS LEARNING MOTIVATION ON PHYSICS LEARN- ING IN SENIOR SECONDARY SCHOOL}

\author{
Nurmalita Sari, Widha Sunarno, Sarwanto \\ PPs Universitas Sebelas Maret Surakarta \\ Jalan Ir. Sutami No. 36A Surakarta 57126 \\ E-mail: nurmalita33@gmail.com \\ widhasunarno@gmail.com \\ sar1to@yahoo.com
}

Naskah diterima tanggal: 10-6-2017, disetujui tanggal: 29-12-2017

\begin{abstract}
The objectives of this research are to 1) find out the profile of student's learning motivation in Physics class measured by aspects such as Attention, Relevation, Confidence, and Satisfaction; and 2) measure the percentage of each learning motivation aspect such as Attention, Relevation, Confidence, and Satisfaction contributed to students' learning motivation in Physics class. The sample of this research is 90 students from XI class of Science Program. The data was collected through questionnaire and observation. The questionnaire was analyzed using descriptive quantitatively while the observation sheet was analyzed qualitatively. The results show that: 1) the student's learning motivation can be categorized into high, average, and low; and 2) the percentage of each learning motivation aspects are Attention (59,86\%), Relevance (57,08\%), Confidence (55,28\%), and Satisfaction $(60,14 \%)$. To conclude, the average level of students'learning motivation for Physics is in the medium and low category caused by the lack of students' interest in learning Physics.
\end{abstract}

Keywords: learning motivation, learning of Physics, ARCS

\begin{abstract}
Abstrak: Tujuan penelitian ini adalah untuk 1) mengetahui profil motivasi belajar siswa ketika mengikuti pembelajaran Fisika di kelas yang diukur berdasarkan aspek perhatian (Attention), relevansi (Relevance), percaya diri (Confidence), dan kepuasan (Satisfaction); 2) mengetahui persentase sumbangan dari tiap aspek motivasi belajar yang terdiri dari perhatian (Attention), relevansi (Relevance), percaya diri (Confidence), dan kepuasan (Satisfaction) dalam menentukan tingkat motivasi belajar siswa ketika mengikuti pembelajaran Fisika di kelas. Penelitian dilaksanakan di SMA Negeri 2 Surakarta, SMA Negeri 5 Surakarta, dan SMA Negeri 6 Surakarta. Sampel penelitian sebanyak 90 siswa kelas XI MIPA. Pengumpulan data menggunakan teknik angket dan observasi. Teknik analisis angket adalah deskriptif kuantitatif, sedangkan lembar observasi dianalisis secara kualitatif. Hasil penelitian menunjukkan bahwa: 1) motivasi belajar siswa untuk mata pelajaran Fisika dikategorikan tinggi, sedang, dan rendah; 2) persentase tiap aspek motivasi belajar adalah (a) aspek perhatian (Attention) sebesar 59,86\%, b) aspek relevansi (Relevance) sebesar $57,08 \%$, c) aspek percaya diri (Confidence) sebesar 55,28\%, d) aspek kepuasan (Satisfaction) sebesar 60,14\%. Kesimpulan, rata-rata tingkat motivasi belajar siswa untuk mata pelajaran Fisika berada dalam kategori sedang dan rendah yang disebabkan kurangnya ketertarikan siswa untuk belajar Fisika.
\end{abstract}

Kata kunci: motivasi belajar, pembelajaran Fisika, ACRS 


\section{PENDAHULUAN}

Fisika dapat diartikan sebagai ilmu yang mempelajari tentang kejadian-kejadian alam yang bersifat fisik dan dapat dipelajari secara pengamatan, eksperimen, dan teori. Hasil-hasil Fisika dapat dinyatakan dalam bentuk fakta, konsep, prinsip, hukum, dan teori. Ilmu Fisika dibelajarkan melalui kegiatan pembelajaran di sekolah melalui serangkaian kegiatan yang dirancang untuk mendukung proses belajar siswa yang bersifat internal (Suparwoto, 2007). Prinsip pembelajaran Fisika yaitu mengedepankan proses ilmiah guna menghasilkan produk serta berlandaskan pada sikap ilmiah. Proses ilmiah dalam pembelajaran Fisika identik dengan pelaksanaan suatu kegiatan dalam metode ilmiah. Produk yang dihasilkan tidak hanya berbentuk benda namun menitikberatkan pada suatu ide atau pemikiran sains. Sikap ilmiah akan terbentuk melalui proses ilmiah yang dilaksanakan untuk menghasilkan produk.

Keterkaitan ketiga aspek tersebut dalam pembelajaran Fisika dapat menunjang adanya kinerja pendidikan yang berkualitas. Perubahan dan perkembangan aspek kehidupan perlu ditunjang oleh pendidikan. Pendidikan yang berkualitas sangat diperlukan untuk mendukung terciptanya manusia yang cerdas serta mampu bersaing di era global. Pendidikan juga berperan penting dalam pembentukan karakter dan perkembangan mental individu, yang nantinya akan tumbuh menjadi seorang manusia dewasa. Nilai-nilai tersebut menjadi bekal individu agar dapat berinteraksi, baik secara individu maupun makhluk sosial.

Pendidikan identik dengan proses belajar. Proses belajar menghasilkan suatu perubahan dalam diri individu yang menyangkut perubahan dalam beberapa aspek. Perubahan perilaku dalam belajar mencakup tiga ranah seperti yang dinyatakan oleh Bloom, Engelhart, Furts, Hill, dan Krathwohl (1956) yaitu ranah kognitif, ranah afektif, dan ranah psikomotor. Dengan demikian, seseorang dikatakan mengalami proses belajar jika terdapat peningkatan perilaku dalam hal kognitif, afektif, dan psikomotor dalam diri orang tersebut. Belajar merupakan suatu proses perubahan dalam diri individu yang menghasilkan perubahan tingkah laku karena hasil interaksi dari sesama maupun lingkungan berdasarkan praktik dan pengalaman tertentu (Uno, 2008).

Proses belajar Fisika yang dilaksanakan oleh siswa sebagai subjek pebelajar tentu saja dipengaruhi oleh beberapa faktor, baik faktor dari diri siswa maupun faktor dari lingkungan. Penelitian dari Hynd, Holschuh, dan Nist (2000) teridentifikasi bahwa faktor-faktor yang memengaruhi proses belajar siswa dalam bidang sains berasal dari dalam diri siswa dan guru. Faktor yang berasal dari diri siswa termasuk dalam kelompok faktor internal, meliputi antara lain motivasi belajar sains, faktor ketertarikan siswa terhadap pelajaran sains, faktor orientasi atau tujuan belajar siswa, dan faktor keinginan siswa untuk lebih mempelajari alam. Faktor dari guru yang terangkum dalam faktor eksternal, antara lain kurikulum, interaksi guru dengan siswa dan model pembelajaran yang diterapkan oleh guru.

Salah satu faktor internal yang berpengaruh terhadap proses belajar siswa dalam mempelajari ilmu Sains adalah motivasi. Motivasi merupakan salah satu faktor yang berpengaruh terhadap kegiatan yang sedang dijalankan oleh seorang individu. Sebagaimana dikemukakan oleh Glynn, Brickman, Armstrong, dan Taasoobshirazi (2011), motivasi merupakan daya penggerak dari dalam diri siswa untuk melakukan aktivitasaktivitas tertentu demi mencapai suatu tujuan dalam belajar Sains. Busato, Prins, Elshout, dan Hamaker (2000) menjelaskan hasil penelitiannya tentang faktor-faktor yang berpengaruh terhadap prestasi belajar siswa meliputi kemampuan intelektual siswa, gaya belajar siswa, dan motivasi belajar siswa. Namun, hasil penelitian menunjukkan bahwa kemampuan intelektual dan motivasi belajar berkorelasi positif terhadap prestasi belajar. 
Motivasi belajar siswa dapat diukur menggunakan instrumen yang dikembangkan berdasarkan aspek-aspek dari motivasi belajar. Keller (1987) mengembangkan aspek-aspek yang dapat digunakan untuk mengukur tingkat motivasi belajar siswa yang dinamakan ARCS (Attention Relevance Confidence Satisfaction). ARCS yang dikembangkan oleh Keller didasarkan pada sintesis dari konsep motivasi dan karakteristik motivasi yang dikelompokkan menjadi empat aspek yaitu Attention (perhatian), Relevance (relevansi), Confidence (percaya diri), dan Satisfaction (kepuasan). Attention (perhatian) yaitu sikap yang ditunjukkan oleh siswa dengan memberi atensi atau pemfokusan diri terhadap pembelajaran Fisika. perhatian siswa timbul karena rasa ingin tahu. Relevance (relevansi) adalah pandangan siswa tentang keterkaitan antara manfaat dan aplikasinya pada kehidupan sehari-hari. Motivasi belajar siswa akan terjaga apabila siswa dapat menemukan hubungan antara apa yang dipelajari dengan manfaatnya dalam memenuhi kebutuhan pribadi maupun sesuai dengan nilai yang diyakini. Confidence (percaya diri) adalah keyakinan diri siswa dalam belajar Fisika dan menyelesaikan masalah Fisika. siswa yang memiliki rasa bahwa dirinya berkompeten atau mampu dalam belajar Fisika, maka keinginan untuk belajar Fisika semakin baik. Satisfaction (kepuasan) yaitu rasa puas dari dalam diri siswa dalam memecahkan permasalahan Fisika yang sedang dipelajari.

Penelitian dari Cicuto dan Torres (2016) menguatkan bahwa lingkungan belajar yang aktif dapat memotivasi siswa untuk lebih belajar dengan keras. Lingkungan belajar yang aktif didukung oleh proses pembelajaran yang aktif pula. Penelitian dari Velayutham, Aldridge, dan Fraser (2011) mendukung teori yang menyatakan pentingnya tingkat motivasi belajar siswa untuk mata pelajaran Sains. Tantangan awal untuk seorang guru adalah membangkitkan motivasi belajar Sains dari para siswa. Motivasi belajar
Sains merupakan komponen afektif yang sangat penting karena motivasi belajar melandasi proses pengkonsepsian suatu materi, berpikir kritis, strategi dalam belajar, dan keberhasilan dalam belajar. Hal tersebut diperkuat dari hasil penelitian Fyan dan Maehr (dalam Budiawan \& Arsani, 2013) bahwa terdapat tiga faktor yang mempengaruhi hasil belajar siswa yaitu latar belakang keluarga, kondisi atau konteks sekolah, dan motivasi. Simpulan penelitian bahwa faktor terakhirlah yang merupakan faktor penentu tingkat prestasi belajar siswa.

Fisika yang dibelajarkan oleh guru di kelas menekankan proses pembelajaran yang menuntut kemampuan siswa secara perhitungan matematis, logis, rasional, dan verbal (Rahman, 2004). Titik berat Fisika untuk pemahaman matematis cenderung membuat siswa beranggapan bahwa Fisika adalah pelajaran yang sulit. Hasil belajar siswa untuk mata pelajaran Fisika tergolong rendah. Berdasarkan data nilai UAS Semester 1 tahun pelajaran 2016/2017 untuk mata pelajaran Fisika dari 3 SMA di Kota Surakarta diperoleh bahwa hanya $40 \%$ dari seluruh siswa kelas XI yang memiliki nilai di atas KKM sebesar 75. Siswa-siswa yang mendapatkan nilai di bawah KKM harus tes kembali atau melaksanakan remediasi agar hasil kognitif dalam mata pelajaran Fisika mencapai ketuntasan. Hasil observasi ketika pembelajaran Fisika ditemukan bahwa kesungguhan sebagian besar siswa dalam belajar Fisika kurang terlihat. Siswa tidak berperan aktif di kelas. Hal tersebut didukung oleh hasil penelitian Rahman (2004) yang mengemukakan bahwa kebanyakan siswa tidak memiliki motivasi belajar yang baik dan sikap positif terhadap pelajaran Fisika. Hal tersebut ditandai dengan tidak adanya kesungguhan siswa dalam belajar Fisika dan kelalaian siswa untuk mengerjakan tugas dari guru Fisika. Akibatnya, hasil belajar Fisika rendah.

Berdasarkan uraian tersebut, diperlukan penelitian untuk mengetahui tingkat motivasi 
belajar siswa dalam mengikuti pembelajaran Fisika di kelas. Hal itu dilandasi oleh faktor motivasi belajar berperan penting dalam proses belajar, dan tingkat motivasi belajar siswa yang telah diketahui dapat dijadikan pedoman guru dalam melaksanakan proses pembelajaran yang lebih baik.

Rumusan masalah dalam penelitian ini adalah: 1) Bagaimanakah profil motivasi belajar siswa ketika mengikuti pembelajaran Fisika di kelas yang diukur berdasarkan aspek-aspek ARCS?; 2) Bagaimanakah persentase tiap aspek ARCS dalam menyumbangkan tingkat motivasi belajar siswa ketika mengikuti pembelajaran Fisika di kelas?

Tujuan penelitian ini adalah: 1) Mengetahui profil motivasi belajar siswa ketika mengikuti pembelajaran Fisika di kelas yang diukur berdasarkan aspek-aspek ARCS; dan 2) Mengukur persentase sumbangan dari tiap aspek ARCS dalam menentukan tingkat motivasi belajar siswa ketika mengikuti pembelajaran Fisika di kelas.

Berdasarkan uraian dari tujuan penelitian, maka manfaat dari penelitian ini adalah untuk mengetahui tingkat motivasi belajar siswa yang dalam pembelajaran Fisika serta untuk merumuskan suatu kebijakan dalam dunia pendidikan berkaitan dengan proses pembelajaran Fisika di sekolah.

\section{METODE}

Penelitian dilaksanakan pada bulan Januari 2017 sampai Maret 2017. Populasi penelitian yaitu siswa kelas XI MIPA dari SMA Negeri 2 Surakarta, SMA Negeri 5 Surakarta, dan SMA Negeri 6 Surakarta. Penentuan populasi dilakukan secara sengaja atau purposive. Penentuan sampel penelitian dilakukan dengan teknik random sampling. Penentuan jumlah sampel penelitian ditentukan berdasarkan pendapat dari Sugiyono (2012), yaitu jika jumlah populasi kurang dari 100 maka seluruh populasi tersebut digunakan sebagai sampel. Jika populasi lebih dari 100 maka jumlah sampel yang digunakan untuk subjek penelitian dapat diambil $10 \%-15 \%$ dari total populasi. Sampel yang digunakan dalam penelitian ini sebanyak 90 siswa kelas XI MIPA dari ketiga SMA tersebut.

Sampel penelitian untuk mengukur tingkat motivasi belajar sebanyak 90 siswa yang berasal dari kelas XI MIPA. Sampel penelitian berasal dari tiga sekolah di kota Surakarta yaitu SMA Negeri 2 Surakarta, SMA Negeri 5 Surakarta, dan SMA Negeri 6 Surakarta. Setiap sekolah diambil 30 siswa dari salah satu kelas XI MIPA.

Pengumpulan data dalam penelitian ini menggunakan teknik angket dan observasi. Teknik angket digunakan untuk mengetahui persentase dari tingkat motivasi belajar Fisika setiap siswa. Teknik observasi digunakan sebagai data pendukung melalui pengamatan siswa secara klasikal yang mencerminkan tingkat motivasi belajar siswa ketika pembelajaran Fisika di kelas.

Instrumen penelitian berupa angket dan lembar observasi. Pengukuran motivasi belajar didasarkan pada aspek motivasi belajar yang dikembangkan oleh Keller (1987) yang terdiri dari aspek perhatian (attention), relevansi (relevance), percaya diri (confidence), dan kepuasan (satisfaction) atau disebut juga ARCS. Aspek ARCS tersebut kemudian dikembangkan menjadi beberapa indikator.

Teknik analisis data untuk angket motivasi belajar secara deskriptif kuantitatif. Metode penskoran angket motivasi belajar siswa didasarkan pada skala Likert dengan 4 pilihan jawaban. Pilihan jawaban yang disediakan untuk angket motivasi belajar Fisika antara lain $4=$ selalu, 3 = kadang-kadang, 2 = jarang, $1=$ tidak pernah. Motivasi belajar Fisika dikelompokkan menjadi tiga kategori, yaitu tinggi, sedang, dan rendah. Teknik analisis data untuk mengetahui kategori motivasi belajar Fisika melalui angket dilaksanakan dengan mengakumulasikan skor dari semua butir angket dari semua sampel penelitian. Skor tersebut 
kemuadian diolah untuk menentukan rata-rata skor motivasi belajar dan deviasi standar. Ratarata dan deviasi standar digunakan sebagai patokan untuk mengkategorikan tingkat motivasi belajar tiap siswa untuk mata pelajaran Fisika. Kriteria pengelompokan kategori motivasi belajar siswa untuk mata pelajaran Fisika disajikan pada Tabel 1.

Tabel 1 Kategori Pengukuran Motivasi Belajar Siswa dalam Pembelajaran Fisika

\begin{tabular}{ccl}
\hline No & Rentang Skor & Kategori \\
\hline 1 & $X \geq \bar{X}+S D$ & Tinggi \\
2 & $\bar{X}-S D \leq X<\bar{X}+S D$ & Sedang \\
3 & $X<\bar{X}-S D$ & Rendah \\
\hline
\end{tabular}

Sumber: Arikunto (2008).

Keterangan:

$X$ : skor motivasi belajar Fisika tiap siswa

: rata-rata skor motivasi belajar Fisika seluruh siswa.

$\bar{X}$ : standar deviasi atau simpangan baku dari skor motivasi belajar Fisika seluruh siswa.

Langkah selanjutnya adalah menentukan persentase $(\%)$ dari tiap kategori motivasi belajar. Motivasi belajar Fisika yang dikategorikan menjadi kelompok motivasi tinggi, sedang, dan rendah ditentukan persentasenya untuk mengetahui tingkatan motivasi belajar siswa secara umum ketika belajar Fisika. Cara menentukan persentase tiap kategori motivasi belajar Fisika adalah sebagai berikut.

$$
A=\frac{N}{T} \times 100 \%
$$

\section{Keterangan:}

$A$ : kategori motivasi belajar siswa tinggi/ sedang/rendah, dengan satuan persen (\%).

$N$ : jumlah siswa yang memiliki motivasi belajar tinggi/sedang/rendah.

$T$ : jumlah seluruh siswa atau sampel penelitian.
Hasil analisis dari angket tersebut digunakan untuk mengetahui tingkat motivasi belajar siswa selama mengikuti pembelajaran Fisika yang dinyatakan dalam persentase dari masingmasing kategori motivasi tinggi, sedang, dan rendah. Selain itu, melalui data dari angket motivasi belajar siswa dapat dihitung persentase dari tiap-tiap aspek ARCS untuk motivasi belajar Fisika. Cara menghitung persentase tiap aspek ARCS dari angket motivasi belajar siswa adalah sebagai berikut.

$$
M=\frac{X}{Y} \times 100 \%
$$

Keterangan:

$M$ : persentase tiap aspek ARCS (Attention, Relevance, Confidence, Satisfaction).

$X$ : skor dari aspek A (Attention)/R (Relevance)/ $\mathrm{C}$ (Confidence)/ S (Satisfaction) dari seluruh angket siswa.

$Y$ : skor ideal dari aspek A (Attention)/ R (Relevance)/C (Confidence)/S (Satisfaction) atau skor kriteria dari aspek $A / R / C /$ $\mathrm{S}$.

Angket motivasi belajar Fisika divalidasi oleh dosen ahli dan diujicobakan kepada siswa sebelum digunakan untuk penelitian. Validasi isi dimaksudkan untuk melihat kesesuaian indikator dengan aspek motivasi belajar ARCS, kesesuaian butir-butir pernyataan angket dengan indikator motivasi belajar, dan susunan kalimat. Validator isi untuk angket motivasi belajar Fisika yaitu Sukarmin, S.Pd., M.Si., Ph.D. selaku dosen Prodi Magister Sains Universitas Sebelas Maret Surakarta. Setelah melalui proses validasi isi, angket motivasi belajar Fisika kemudian diujicobakan kepada 30 siswa kelas X SMA Negeri 5 Surakarta untuk melihat reliabilitas angket. Reliabilitas angket motivasi belajar Fisika ditentukan jika nilai sama dengan atau lebih besar daripada 0,70 berarti tes hasil belajar mempunyai reliabilitas yang tinggi (Sudijono, 2010).

Lembar observasi digunakan oleh observer dalam mengamati tingkah laku siswa yang 
merupakan cerminan dari aspek motivasi belajar Fisika. Hasil pengamatan tersebut digunakan sebagai data pendukung angket motivasi belajar Fisika. Lembar observasi dianalisis secara kualitatif. Sugiyono (2012) mengemukakan teknik analisis data secara kualitatif terdiri dari tiga tahapan utama antara lain: 1) Reduksi Data (Data Reduction), yaitu kegiatan merangkum, memilih hal-hal pokok, dan memfokuskan data hasil observasi sesuai dengan fokus dari aspek motivasi belajar Fisika yang sedang dikaji; 2) Penyajian Data (Data Display), yaitu data hasil observasi yang telah dirangkum melalui kegiatan reduksi data kemudian disajikan dalam bentuk naratif; 3) Penarikan Simpulan (Conclusion Drawing), yaitu data hasil observasi yang disajikan dalam bentuk naratif kemudian digeneralisasikan untuk didapatkan simpulan. Simpulan tersebut akan mewakili semua data atau informasi dari hasil pengamatan motivasi belajar siswa berdasarkan aspek ARCS.

\section{HASIL DAN PEMBAHASAN}

Motivasi belajar diukur menggunakan angket dan lembar observasi berdasarkan indikator-indikator aspek ARCS. Indikator-indikator motivasi belajar yang diukur berdasarkan aspek ARCS disajikan pada Tabel 2.

Angket motivasi belajar Fisika divalidasi oleh validator ahli dan diujicobakan kepada 30 siswa kelas X MIPA di SMA Negeri 5 Surakarta. Hasil estimasi reliabilitas untuk angket motivasi belajar Fisika menunjukkan nilai reliabilitas (Cronbach's alpha) 0,843. Hasil tersebut menunjukkan bahwa butir-butir angket motivasi belajar Fisika yang disusun berdasarkan aspek ARCS termasuk dalam kategori reliabilitas yang tinggi (reliable). Instrumen angket yang telah divalidasikan kepada dosen ahli untuk validasi isi dan diujicobakan dengan hasil memiliki nilai reliabilitas yang tinggi, kemudian instrumen angket tersebut siap digunakan sebagai instrumen penelitian.

Angket motivasi belajar Fisika diberikan kepada para siswa setelah mengikuti pelajaran Fisika. Selama proses pembelajaran Fisika juga dilaksanakan observasi secara klasikal untuk mengamati motivasi belajar siswa-siswa di kelas. Hasil pengamatan tersebut dijadikan data pendukung profil motivasi belajar Fisika berdasarkan angket.

Hasil dari penelitian menunjukkan bahwa rata-rata skor motivasi belajar dari 90 siswa adalah 18,59. Simpangan baku dari skor motivasi belajar seluruh siswa adalah 5,27. Rata-rata dan simpangan baku dari skor motivasi belajar siswa tersebut digunakan untuk mengelompokkan tingkat motivasi siswa dalam belajar Fisika.

Tabel 2 Indikator Motivasi Belajar Siswa Berdasarkan Aspek ARCS

\begin{tabular}{|c|c|c|}
\hline No & Aspek & Indikator \\
\hline 1 & $\begin{array}{l}\text { Attention } \\
\text { (Perhatian) }\end{array}$ & $\begin{array}{l}\text { a. Perhatian terhadap proses pembelajaran } \\
\text { b. Kemauan siswa untuk mencari dan menemukan informasi } \\
\text { yang berkaitan dengan materi Fisika }\end{array}$ \\
\hline 2 & $\begin{array}{l}\text { Relevance } \\
\text { (Relevansi) }\end{array}$ & $\begin{array}{l}\text { a. Mampu mengaitkan konsep-konsep dari materi } \\
\text { b. Menyebutkan aplikasi dari konsep Fisika dalam kehidupan } \\
\text { sehari-hari }\end{array}$ \\
\hline 3 & $\begin{array}{l}\text { Confidence } \\
\text { (Percaya } \\
\text { Diri) }\end{array}$ & $\begin{array}{l}\text { a. Berani menyampaikan pendapat atau menjawab pertanyaan } \\
\text { b. Menyelesaikan masalah terkait materi Fisika secara mandiri }\end{array}$ \\
\hline 4 & $\begin{array}{l}\text { Satisfaction } \\
\text { (Kepuasan) }\end{array}$ & $\begin{array}{l}\text { a. Berusaha aktif dalam kegiatan pembelajaran Fisika } \\
\text { b. Mengerjakan tugas, proyek, latihan soal, dan soal ulangan } \\
\text { Fisika dengan tuntas }\end{array}$ \\
\hline
\end{tabular}


Total skor dari jawaban angket motivasi belajar Fisika yang telah diisi oleh siswa kemudian dihitung dan dicocokkan dengan kriteria tingkat motivasi pada Tabel 1 . Skor angket motivasi belajar Fisika dari siswa dianalisis kemudian dikelompokkan menjadi motivasi belajar tinggi, sedang, dan rendah. Jumlah siswa dengan kategori motivasi belajar Fisika yang dikelompokkan menjadi tiga kategori disajikan dalam Tabel 3.

Tabel 3 Jumlah Siswa Menurut Pengelompokkan Motivasi Belajar Fisika

\begin{tabular}{ccc}
\hline No & $\begin{array}{c}\text { Kategori Motivasi } \\
\text { Belajar Fisika }\end{array}$ & Banyak Siswa \\
\hline 1 & Tinggi & 17 \\
2 & Sedang & 53 \\
3 & Rendah & 20 \\
\hline
\end{tabular}

Jumlah siswa kelas XI MIPA yang termasuk dalam kategori motivasi belajar tinggi sebanyak 17 siswa, kategori motivasi belajar sedang ada 53 siswa, dan kategori motivasi belajar rendah sebanyak 20 siswa. Hasil analisis data tersebut lalu diubah dalam bentuk persentase. Hasil persentase untuk tiap kategori motivasi belajar Fisika adalah sebanyak 18,89\% siswa dengan motivasi belajar Fisika tinggi; 58,89\% siswa termasuk dalam kategori motivasi belajar sedang; serta 22,22\% siswa bermotivasi belajar Fisika rendah. Berdasarkan hasil tersebut dapat disimpulkan bahwa motivasi belajar siswa untuk mata pelajaran Fisika termasuk dalam kategori sedang. Diagram batang untuk menggambarkan masing-masing kategori motivasi belajar pada mata pelajaran Fisika berdasarkan aspek ARCS disajikan pada Gambar 1.

Hasil dari penelitian yang ditunjukkan dalam Gambar 1 menjelaskan bahwa sebagian besar siswa SMA termasuk dalam kategori motivasi belajar sedang ketika mengikuti pelajaran Fisika dengan persentase terbesar yaitu 58,89\%. Hasil penelitian diperkuat oleh penelitian Indah, Sunarno, dan Sarwanto (2016) yang mengukur

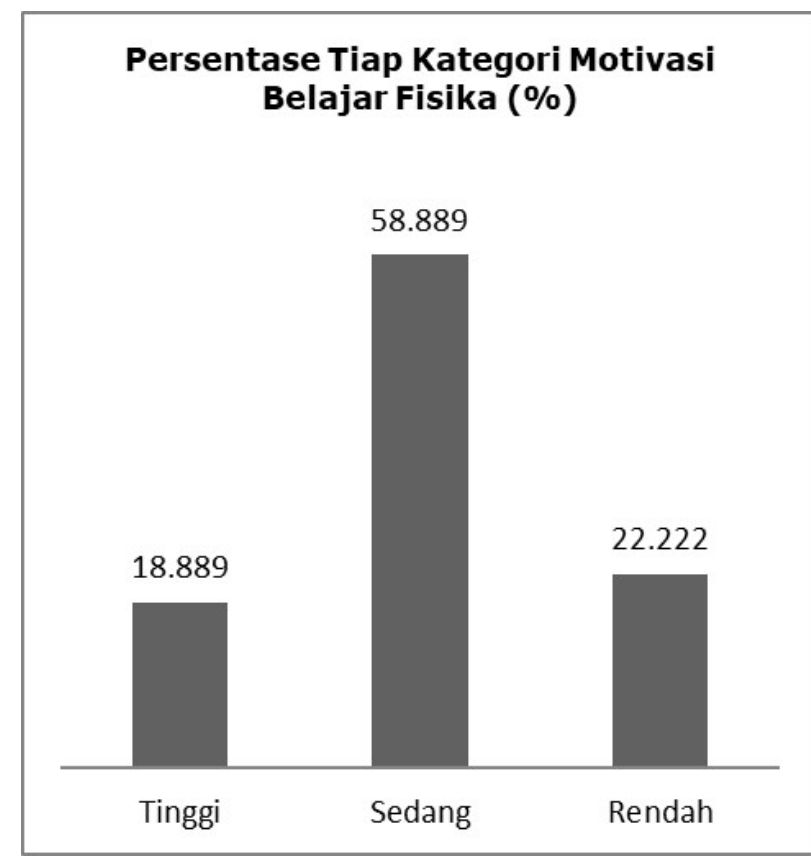

Gambar 1 Persentase dari Tiap Kategori Motivasi Belajar Siswa untuk Mata Pelajaran Fisika SMA

tingkat motivasi belajar Fisika menggunakan aspek ARCS. Simpulan yang diperoleh yaitu rata-rata dari keempat aspek ARCS sebesar $34 \%$. Persentase tersebut termasuk dalam kategori motivasi belajar sedang.

Siswa memiliki daya penggerak yang cukup baik ketika mengikuti proses pembelajaran Fisika di kelas, sehingga menjadi motivasi untuk belajar Fisika yang berasal dari dalam diri siswa. Daya penggerak yang dimiliki oleh siswa kemudian tercermin dari sikap dan tindakan siswa ketika mengikuti proses pembelajaran Fisika di kelas. Berdasarkan analisis angket motivasi belajar dan observasi ketika pembelajaran Fisika, siswa memberikan perhatian (attention) yang baik ketika pembelajaran Fisika berlangsung. Sebagian besar siswa memperhatikan penjelasan guru karena siswa menganggap bahwa Fisika merupakan salah satu mata pelajaran yang cukup sulit. Perhatian siswa yang tinggi ketika pelajaran Fisika tidak serta merta menjadikan siswa memiliki rasa percaya diri (confidence) yang tinggi. Hal tersebut diperkuat dari hasil angket motivasi belajar dan hasil observasi bahwa siswa kurang mampu menjawab 
pertanyaan dari guru yang ditunjukkan kepada siswa ketika diskusi pelajaran Fisika. Ada siswa yang berusaha mencari jawabannya tetapi siswa tersebut tidak memiliki keberanian untuk mengungkapkan pendapatnya. Guru harus menunjuk satu per satu siswa agar siswa berani memberikan pendapat di kelas. Motivasi belajar siswa yang termasuk dalam kategori sedang dapat menggambarkan bahwa hanya sebagian kecil siswa yang kurang memahami relevansi (relevance) atau keterkaitan materi Fisika yang sedang dipelajari dengan aplikasi dalam kehidupan sehari-hari. Sebagian besar dari siswa kelas XI SMA jurusan MIPA telah mampu memahami manfaat belajar Fisika. Oleh karena itu, nilai kepuasan siswa (satisfaction) setelah belajar Fisika menjadi maksimal.

Berdasarkan diagram batang pada Gambar 1 , dapat dilihat bahwa jumlah siswa yang bermotivasi belajar rendah $(22,22 \%)$ lebih banyak daripada jumlah siswa yang bermotivasi belajar tinggi $(18,89 \%)$. Fisika masih dianggap sebagai mata pelajaran yang sulit oleh sebagian besar siswa, yaitu untuk mempelajari konsep Fisika dan persamaan matematisnya. Persamaan matematis tersebut yang membuat siswa tidak tertarik belajar Fisika. Hasil angket tersebut didukung dengan hasil observasi bahwa siswa yang tergolong dalam motivasi belajar rendah, kurang antusias dalam mengikuti pelajaran Fisika di kelas. Siswa yang bermotivasi belajar Fisika rendah, kurang fokus menerima pelajaran Fisika yang disampaikan oleh guru. Selain itu, siswa enggan menyelesaikan permasalahan yang berkaitan dengan materi Fisika dengan tuntas. Samsudin, Suhendi, Efendi, dan Suhandi (2012) juga menyatakan bahwa motivasi belajar siswa untuk mata pelajaran Fisika termasuk kategori rendah. Kategori rendah tersebut dinyatakan dengan rata-rata skor motivasi siswa hanya 60,2 yang terlihat dari persentase masing-masing aspek motivasi belajar Fisika. Kelima aspek motivasi belajar Fisika yang dijadikan subjek penelitian antara lain menyelesaikan soal-soal yang ada (56\%), berusaha memahami teori yang diajarkan (62\%), ketertarikan pada materi Fisika $(68 \%)$, semangat dalam mempelajari materi $(58 \%)$, dan berusaha memperhatikan pelajaran di kelas (57\%).

Motivasi belajar Fisika yang tergolong dalam kategori tinggi hanya 18,89\%. Hasil penelitian menggambarkan bahwa hanya sebagian kecil siswa yang antusiasi dan memiliki motivasi belajar tinggi untuk mengikuti proses pembelajaran Fisika dari awal hingga akhir. Siswa tersebut lebih dominan di dalam kelas daripada siswa yang memiliki motivasi belajar sedang bahkan rendah; memiliki tujuan tertentu ketika belajar Fisika; memiliki rasa percaya diri ketika diskusi kelas maupun mengerjakan soal latihan; serta aktif bertanya kepada guru tentang terapan konsep Fisika dalam kehidupan seharihari.

Motivasi belajar berupa daya penggerak dalam diri siswa dalam belajar Fisika yang merupakan kelompok Sains sangat penting untuk diketahui. Velayutham, et al., (2011) melakukan penelitian tentang latar belakang pentingnya mengetahui motivasi belajar siswa dalam pembelajaran Sains. Motivasi belajar Sains melandasi proses pengkonsepsian suatu materi, berpikir kritis, strategi dalam belajar, dan keberhasilan dalam belajar. Motivasi belajar yang merupakan bentuk dorongan dari diri siswa berperan penting dalam proses belajar siswa sebagai subJek pebelajar. Motivasi tersebut mendorong siswa untuk memiliki suatu cita-cita atau tujuan dalam belajar. Motivasi dalam belajar Fisika akan berperan dalam menghantarkan siswa mencapai tujuannya dalam mempelajari konsep Fisika.

Motivasi belajar Fisika yang terukur dari penelitian berdasarkan aspek-aspek ARCS. Persentase tiap aspek ARCS yang terukur disajikan dalam Gambar 2. Berdasarkan Gambar 2 dapat diperoleh gambaran bahwa aspek motivasi belajar yang diukur menggunakan indikator ARCS memiliki persentase yang 


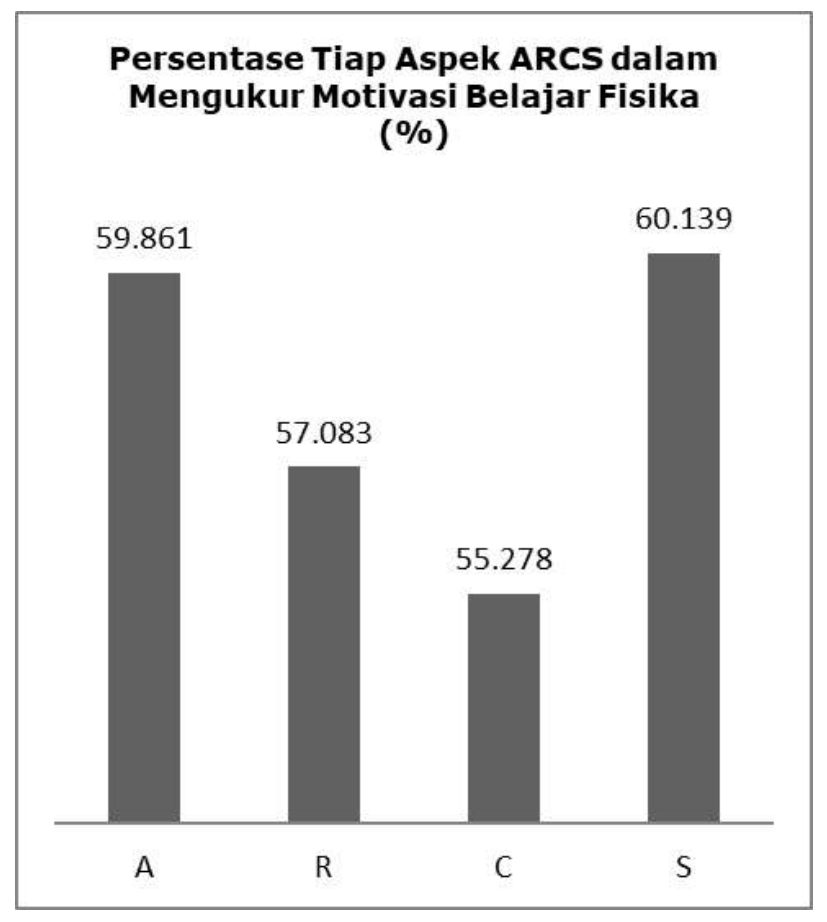

Gambar 2 Persentase Tiap Indikator ARCS dari Motivasi Belajar Siswa untuk Mata Pelajaran Fisika

berbeda-beda dalam memengaruhi besarnya motivasi siswa dalam belajar Fisika. Indikatorindikator ARCS yang terukur antara lain perhatian (attention) memiliki persentase sebesar 59,86\%; relevansi (relevance) sebesar $57,08 \%$; percaya diri (confidence) sebesar $55,28 \%$; dan kepuasan (satisfaction) sebesar $60,14 \%$. Aspek percaya diri (Confidence) menempati presentase yang paling rendah diantara indikator ARCS yang lain. Aspek kepuasan (Satisfaction) menempati persentase yang paling tinggi dalam menumbuhkan motivasi belajar Fisika.

Indikator ARCS yang pertama ialah perhatian (attention). Berdasarkan hasil yang diperoleh bahwa siswa memiliki aspek perhatian (attention) terhadap mata pelajaran Fisika sebesar 59,86\%. Indikator-indikator motivasi belajar dari aspek perhatian (attention) antara lain adanya kemauan siswa dalam memberi atensi atau fokus terhadap proses pembelajaran Fisika di kelas serta kemauan siswa dalam mencari dan menemukan informasi yang berkaitan dengan materi Fisika. Bentuk perhatian atau atensi yang diberikan oleh siswa ketika mengikuti pelajaran Fisika dapat terlihat dari kemauan siswa untuk mencatat materi Fisika, memperhatikan penjelasan guru di depan kelas, atau siswa tidak melakukan kegiatan lain ketika mengikuti pelajaran Fisika. Bentuk kemauan siswa untuk mencari informasi berkaitan dengan belajar Fisika dapat terlihat dari keberanian siswa menyampaikan pertanyaan kepada guru ketika menemui kesulitan dan siswa aktif membaca buku untuk memperdalam materi Fisika. Aspek perhatian yang termasuk dalam aspek motivasi belajar ARCS memberi sumbangan sebesar $59,86 \%$ dalam mendorong siswa untuk belajar Fisika. Persentase tersebut didasarkan pada pengisian angket motivasi belajar oleh siswa setelah belajar Fisika. Hasil observasi atau pengamatan terhadap motivasi belajar siswa untuk aspek perhatian (attention) yang dilaksanakan ketika proses pembelajaran Fisika adalah siswa-siswa yang tergolong dalam motivasi belajar tinggi dan sedang memberi perhatian yang cukup baik ketika jam pelajaran Fisika. Aspek perhatian memberikan kontribusi yang cukup tinggi karena memperhatikan merupakan sikap yang mudah dilaksanakan oleh siswa. Hal tersebut sesuai dengan penelitian Indah, et al. (2016) yang menjelaskan bahwa aspek perhatian (attention) dari siswa adalah indikator motivasi belajar yang memiliki persentase cukup tinggi. Siswa-siswa tingkat Sekolah Menengah Atas telah memiliki kesadaran yang tinggi untuk memfokuskan pikiran ketika pelajaran di kelas.

Hasil observasi juga menemukan bahwa siswa dengan motivasi belajar rendah hanya memperhatikan pelajaran Fisika di bagian awal saja. Siswa merasa mudah bosan mengikuti penjelasan guru di depan kelas. Siswa tidak memiliki konsentrasi yang tinggi sehingga fokus siswa tidak terarah. Dalam hal ini guru harus mampu membangkitkan motivasi siswa khususnya dalam memperhatikan pelajaran. 
Guru dapat menggunakan metode mengajar yang bervariasi selama jam pelajaran Fisika. Guru dapat membimbing siswa yang kurang memperhatikan dengan memberi pertanyaan yang mudah. Selain itu, penggunaan media pembelajaran yang menarik dan edukatif dapat diterapkan agar perhatian siswa selalu tercurah selama jam pelajaran Fisika berlangsung.

Interaksi antara guru dan siswa dapat menciptakan kestabilan bentuk atensi atau perhatian siswa selama mengikuti pelajaran di kelas. Dalam penelitiannya, Christophel (1990) mengungkapkan bahwa ketika guru menciptakan hubungan komunikasi yang dekat dengan siswa baik secara verbal maupun nonverbal, maka belajar siswa akan meningkat. Komunikasi dari guru tidak dalam bentuk paksaan untuk belajar. Christophel juga mengungkapkan bahwa interaksi dalam bentuk komunikasi yang baik antara guru dan siswa dapat menambah motivasi siswa untuk belajar.

Indikator ARCS yang kedua ialah relevansi (relevance). Penelitian ini menunjukkan bahwa siswa-siswa memiliki aspek relevansi (Relevance) terhadap mata pelajaran Fisika sebesar 57,08\%. Indikator motivasi belajar Fisika dari aspek relevansi (relevance) antara lain kemampuan siswa dalam mengaitkan konsep-konsep Fisika dari materi yang telah dipelajari sebelumnya dengan materi Fisika yang sedang dipelajari. Siswa menunjukkan antusias dengan mampu menyebutkan penerapan dari konsep Fisika yang dipelajari dalam bidang teknologi maupun kehidupan sehari-hari. Siswa yang termotivasi untuk belajar Fisika dapat ditunjukkan dengan adanya dorongan dari diri siswa untuk dapat mengaitkan konsep-konsep fisis yang berkaitan satu dengan yang lainnya. Konsep Fisika yang dibelajarkan pada tingkat Sekolah Menengah Atas tidak berdiri sendiri. Antarmateri Fisika yang dipelajari siswa saling berkaitan. Oleh karena itu, siswa harus belajar keras untuk memahami konsep Fisika beserta bentuk matematisnya. Konsep Fisika yang dipelajari oleh siswa juga berkaitan dengan fenomena dalam kehidupan sehari-hari. Sebagai contoh peristiwa dari materi fluida dalam kehidupan sehari-hari antara lain aliran darah dalam tubuh manusia, naiknya asap pabrik melalui cerobong asap, aliran air sungai, dan sebagainya. Selain dalam kehidupan seharihari yang biasa dilihat atau dirasakan oleh indera manusia, ilmu Fisika juga digunakan sebagai dasar pengembangan alat-alat dalam bidang teknologi. Aplikasi tersebut antara lain prinsip termodinamika yang diterapkan pada kulkas, prinsip dari fluida pada venturimeter yang diterapkan untuk karburator, dan sebagainya. Rata-rata siswa tingkat Sekolah Menengah Atas belum memahami relevansi dari konsep fisis dan aplikasinya. Oleh karena itu, motivasi belajar siswa untuk mata pelajaran Fisika menjadi kurang maksimal. Siswa belum memahami dan menyadari sepenuhnya manfaat dari belajar Fisika dalam kehidupannya. Sumbangan aspek relevansi menurut hasil angket hanya $57,08 \%$. Menurut hasil observasi secara general, sebagian besar siswa tidak dapat menjawab pertanyaan dari guru tentang aplikasi materi Fisika yang sedang dipelajari. Untuk keterkaitan antarmateri, hanya sebagian siswa saja yang dapat mengulas kembali materi Fisika sebelumnya dan mengaitkan hubungannya dengan materi Fisika sekarang. Guru harus mampu merangsang keingintahuan siswa tentang fenomena sehari-hari dan aplikasi dalam bidang teknologi dari materi-materi Fisika. Guru dapat memberi penugasan kepada siswa untuk mencari informasi mengenai penerapan konsep Fisika. Lalu siswa diminta untuk mempresentasikan hasil penemuannya agar motivasi belajar siswa meningkat. Pembelajaran Fisika akan lebih bermakna jika siswa dapat mengetahui manfaat dari ilmu yang sedang dipelajari. Hasil dari aspek relevansi sesuai dengan hasil penelitian Indah, et al. (2016) yang menjelaskan bahwa persentase dari aspek relevansi (relevance) berada di bawah aspek perhatian. Sebagian besar siswa belum mampu memahami 
penerapan dari materi Fisika secara baik. Siswa hanya mengetahui bahwa pelajaran Fisika memfokuskan pikiran siswa belajar persamaanpersamaan yang sulit.

Indikator ARCS yang ketiga ialah percaya diri (confidence). Indikator motivasi belajar dari aspek percaya diri (confidence) antara lain siswa menunjukkan keberanian dalam menyampaikan pendapat ketika diskusi di kelas atau bertanya kepada guru ketika siswa menemui kesulitan dalam belajar Fisika. Rasa percaya diri siswa juga dapat ditampilkan dengan sikap siswa yang mampu menyelesaikan semua kegiatan dalam belajar Fisika secara mandiri. Kegiatan tersebut antara lain menyelesaikan tugas Fisika baik secara individu maupun kelompok dengan penuh tanggung jawab, mengerjakan soal ulangan Fisika dengan sungguh-sungguh, menyelesaikan soal-soal Fisika dengan percaya diri dan tidak menjiplak pekerjaan teman, dan lain sebagainya. Aspek percaya diri (confidence) yang termasuk dalam aspek motivasi belajar ARCS memberi sumbangan sebesar 55,28\% dalam mendorong siswa untuk belajar Fisika. Persentase tersebut merupakan persentase aspek motivasi ARCS yang paling rendah diantara aspek lain. Persentase tersebut didasarkan pada hasil analisis angket motivasi belajar oleh siswa. Penelitian dari Indah, et al. (2016) juga sejalan dengan hasil penelitian ini, yaitu aspek percaya diri dari siswa adalah indikator motivasi belajar yang memiliki persentase paling rendah di antara aspek perhatian, relevansi, dan kepuasan. Persentase aspek percaya diri dari penelitian tersebut sebesar $72,60 \%$, sedangkan aspek perhatian 80,30\%; aspek relevansi 79,7\%; dan aspek kepuasan $77,1 \%$. Rasa percaya diri yang dimiliki siswa dalam belajar Fisika kurang maksimal. Sebagian besar siswa memiliki sikap ragu-ragu dalam menyelesaikan kegiatan dan permasalahan dalam belajar Fisika.

Percaya diri merupakan keyakinan diri atau percaya akan kemampuan diri sendiri dalam belajar Fisika maupun menyelesaikan semua permasalahan terkait Fisika. Penilaian sikap percaya diri siswa tingkat Sekolah Menengah Atas dalam mengikuti pelajaran Fisika juga dilakukan dengan observasi atau pengamatan langsung. Generalisasi dari hasil observasi adalah siswa kurang mandiri dalam mengerjakan latihan soal yang diberikan oleh guru. Sebagian siswa selalu bertanya kepada siswa lain untuk menemukan jawaban yang dianggap benar. Sebagian siswa tersebut tidak ada kemauan untuk mencoba menyelesaikan sendiri pekerjaannya. Menurut pendapat Meir (2002) bahwa kerja sama di antara siswa dapat membawa hasil yang lebih baik daripada kerja individu. Hasil kerja dari komunitas tersebut harus didukung oleh keaktifan semua siswa dalam menemukan informasi guna mencari permasalahan. Namun, komunitas kerja juga dapat memperburuk hasil belajar individu jika siswa tersebut hanya bersikap pasif dalam menyumbangkan ide atau gagasan dalam menyelesaikan masalah belajar. Menurut pendapat tersebut siswa sebaiknya mencoba untuk mengerjakan secara individu terlebih dahulu guna mengasah kemampuannya dalam memahami konsep Fisika. Sikap percaya diri yang tinggi akan memperbaiki motivasi belajar siswa dalam belajar Fisika. Guru dapat meningkatkan rasa percaya diri siswa dengan memberikan kesempatan kepada siswa untuk tampil di depan kelas. Kegiatan tersebut dapat berupa guru memberikan sebuah pertanyaan terkait materi Fisika yang sedang dipelajari lalu guru menunjuk beberapa siswa untuk menyampaikan idenya. Guru memberi bimbingan ketika siswa berusaha menjawab dengan memberi petunjuk-petunjuk agar siswa semakin percaya diri dalam menjawabnya. Rata-rata sumbangan rasa percaya diri dari tingkat motivasi belajar tinggi, sedang, dan rendah adalah cukup kecil jika dibandingkan dengan sumbangan dari aspek motivasi belajar lain. 
Indikator ARCS yang keempat ialah kepuasan (satisfaction). Berdasarkan hasil yang diperoleh bahwa siswa memiliki motivasi belajar untuk aspek kepuasan (satisfaction) terhadap mata pelajaran Fisika sebesar 60,14\%. Kepuasan menyangkut keberhasilan siswa dalam belajar Fisika, dengan indikator antara lain adanya usaha dari dalam diri siswa untuk bersikap aktif selama belajar Fisika di kelas; tercermin dari sikap siswa yang selalu mengerjakan proyek-proyek atau tugas-tugas Fisika secara tuntas. Berdasarkan hasil angket bahwa aspek kepuasan siswa memberikan sumbangan terbesar dalam ranah motivasi belajar Fisika. Hal ini tidak sejalan dengan hasil penelitian dari Indah, et al. (2016) yang menyatakan bahwa aspek kepuasan siswa berada pada urutan ketiga setelah aspek perhatian dan aspek relevansi dengan persentase $77,10 \%$. Hal ini berhubungan dengan aspek percaya diri siswa. Hasil penelitian dari Indah, et al. (2016) adalah rasa percaya diri siswa adalah paling rendah sehingga rasa kepuasan siswa dalam belajar Fisika juga rendah. Siswa merasa kurang berhasil dalam belajar Fisika karena keyakinan dalam dirinya akan kemampuan menyelesaikan permasalahan Fisika lemah.

Hasil angket ARCS dalam penelitian ini menyebutkan bahwa persentase tingkat kepuasan siswa dalam belajar Fisika adalah tertinggi. Siswa merasa puas dengan pembelajaran Fisika yang diikutinya sehingga siswa merasa termotivasi. Menurut indikator pengukuran, siswa dapat menyelesaikan permasalahan Fisika secara tuntas. Namun, dalam menyelesaikannya siswa tidak melandasinya dengan sikap percaya diri. Siswa hanya beranggapan bahwa tugas-tugas Fisika telah dapat diselesaikan. Hasil observasi untuk aspek kepuasan memberikan gambaran bahwa semua siswa menyelesaikan seluruh tugas Fisika yang diberikan oleh guru. Namun di sisi lain, hanya sebagian siswa yang menyelesaikan dengan tuntas dan dikerjakan dengan sungguhsungguh. Guru dapat mendorong aspek kepuasan siswa untuk membangkitkan motivasi belajar dengan memberikan tugas dalam bentuk proyek berupa pembuatan alat sederhana yang berdasarkan prinsip Fisika, membuat suatu artikel berkaitan dengan penerapan konsep Fisika dalam teknologi terkini, dan sebagainya. Proyek tersebut hendaknya dalam bentuk kerja ilmiah yang menghasilkan produk Fisika. Hal tersebut dapat menghilangkan anggapan siswa bahwa Fisika identik dengan menyelesaikan soal latihan yang sulit. Jika siswa dapat menghasilkan suatu produk, maka siswa akan senang belajar Fisika.

Materi Fisika identik dengan mempelajari konsep fisis disertai dengan persamaanpersamaan matematis. Kedua hal tersebut menuntut pemahaman siswa secara bersamaan. Motivasi belajar siswa terhadap mata pelajaran Fisika dari hasil penelitian yang termasuk dalam kategori sedang kurang sejalan dengan pendapat dari Berlian (2011) tentang faktorfaktor yang terkait dengan rendahnya pencapaian belajar siswa. Berlian (2011) menjelaskan bahwa motivasi belajar merupakan faktor yang menjadi alasan utama untuk seseorang dalam mencapai tujuan belajar. Tingkat motivasi belajar siswa tergolong rendah sehingga pencapaian hasil belajar siswa juga tidak maksimal. Penelitian dari Sari (2015) mengungkapkan bahwa motivasi belajar yang dimiliki oleh siswa dalam mata pelajaran Fisika dapat berpengaruh terhadap prestasi belajar atau hasil kognitif. Siswa yang memiliki motivasi belajar rendah mendapatkan hasil belajar kognitif yang rendah pula untuk materi fluida statis.

Motivasi belajar siswa dalam mempelajari kelompok Sains dipengaruhi oleh faktor-faktor yang berasal dari siswa dan guru (Hyind, et al. 2000). Faktor yang berasal dari diri siswa yaitu adanya ketertarikan dan semangat siswa untuk belajar mata pelajaran sains. Faktor dari guru yang berpengaruh terhadap motivasi belajar 
siswa adalah kurikulum, interaksi guru dengan siswa dan model pembelajaran yang diterapkan oleh guru. Pembelajaran Fisika yang termasuk dalam sains dapat dilaksanakan dengan memperhatikan penggunaan model pembelajaran yang diterapkan oleh guru. Selain itu, media pembelajaran juga dapat mempengaruhi semangat siswa dalam belajar Fisika. Penelitian dari Piraksa dan Srisawasdi (2014) dengan melibatkan 66 siswa kelas XI IPA sebuah Sekolah Menengah di Thailand, menunjukkan bahwa penerapan model inkuiri terbimbing yang dikombinasikan dengan laboratorium virtual dapat meningkatkan motivasi belajar siswa pada pelajaran Fisika. Oleh karena itu, guru harus pandai memainkan perannya dalam menggunakan model pembelajaran dan media belajar yang dapat membangkitkan semangat belajar siswa. Dalam kelas Fisika biasanya guru menggunakan metode pembelajaran klasikal dengan dominasi ceramah dan mengharapkan siswa duduk, diam, dengar, catat dan hafal, tanpa diselingi berbagai strategi atau metode yang menantang siswa untuk berpartisipasi dalam proses pembelajaran. Pembelajaran fisika seperti itu terkesan menjemukan dan motivasi belajar siswa rendah (Sirhan, 2007); penyampaian materi kurang menarik dan banyak persamaan matematis (William, 2003). Hal-hal tersebut diduga menjadi salah satu faktor penyebab rendahnya prestasi belajar siswa.

Tingkat motivasi belajar antarsiswa dapat mempengaruhi motivasi belajar siswa lain. Hal tersebut dibuktikan dengan penelitian dari Cicuto dan Torres (2016) bahwa lingkungan belajar yang aktif dapat memotivasi siswa untuk lebih belajar dengan keras. Lingkungan belajar yang aktif didukung oleh proses pembelajaran yang aktif pula. Lingkungan belajar aktif ditumbuhkan oleh siswa dalam proses pembelajaran. Jika sebagian besar siswa memiliki motivasi belajar sedang maka guru dapat membuat meningkatkan kembali tingkat motivasi siswa dengan membuat kelompok kerja yang heterogen. Hal tersebut dilakukan untuk mendorong siswa yang kurang termotivasi.

Hasil observasi untuk pembelajaran Fisika berdasarkan kurikulum 2013 bahwa guru telah menitikberatkan proses inkuiri untuk menunjang keaktifan siswa. Inkuiri merupakan kegiatan penyelidikan yang bertujuan untuk membimbing siswa menemukan konsep Fisika yang sedang dipelajari (Wenning, 2005). Konsep pembelajaran inkuiri memiliki tahapan seperti metode ilmiah yang diawali dengan mengidentifikasi masalah, merumuskan hipotesis, melaksanakan eksperimen, mengasalisis data, dan menarik simpulan. Langkah inkuiri tersebut diterapkan oleh guru ketika proses pengamatan dan pengukuran motivasi belajar siswa untuk mata pelajaran Fisika. Tahapan inkuiri mampu memfokuskan motivasi belajar siswa berdasarkan aspek ARCS. Masalah yang tersaji diawal pembelajaran mampu menarik perhatian siswa untuk terus mengikuti alur pembelajaran. Para siswa juga mendapat bimbingan dari guru agar mampu merumuskan masalah terkait fenomena yang ditampilkan di awal. Tahap ini mampu membangkitkan rasa percaya diri siswa untuk mengungkapkan pendapatnya terkait rumusan masalah. Setelah siswa berani menyatakan permasalahan yang hendak dikaji, hipotesis juga harus dirumuskan oleh siswa sebagai dasar melaksanakan eksperimen. Rumusan hipotesis tersebut mampu membangkitkan motivasi belajar siswa untuk aspek percaya diri dan relevansi. Hipotesis dibuktikan dengan suatu tahap yang disebut eksperimen. Kegiatan eksperimen berdampak pada psikomotorik siswa. Eksperimen membangkitkan motivasi siswa untuk aspek perhatian, percaya diri, relevansi, dan kepuasan. Para siswa dapat bekerja sama dalam mengumpulkan data. Data yang terkumpul diolah oleh para siswa sebagai dasar untuk membuat simpulan. Siswa yang mampu memberikan simpulan terkait eksperimen, maka siswa tersebut akan merasa puas dengan kinerjanya. Hal tersebut sejalan dengan penelitian dari 
Wang, Wu, Yu, dan Lin (2015) bahwa penerapan metode inkuiri mampu meningkatkan motivasi belajar siswa untuk mata pelajaran kelompok sains. Penerapan dari amanat Kurikulum 2013 yang menginginkan pembelajaran berpusat kepada siswa dapat membangkitkan motivasi belajar siswa khususnya mata pelajaran Fisika.

Berdasarkan uraian di atas, kebijakan pendidikan yang dapat diambil terkait dengan tingkat motivasi belajar siswa khususnya dalam mata pelajaran Fisika yaitu berhubungan dengan kemampuan pendidik untuk memilih metode pembelajaran. Metode atau model pembelajaran yang mengedepankan proses inkuiri atau menitikberatkan aktivitas siswa dapat membantu siswa dalam membangkitkan motivasi belajar dalam dirinya. Motivasi belajar merupakan dorongan dari dalam diri siswa yang dipengaruhi pula oleh faktor intrinsik dan ekstrinsik ketika proses pembelajaran. Faktor ekstrinsik berkaitan dengan lingkungan belajar siswa dan metode pembelajaran yang diterapkan oleh guru.

\section{SIMPULAN DAN SARAN}

\section{Simpulan}

Berdasarkan hasil penelitian diperoleh hasil bahwa rata-rata tingkat motivasi belajar siswa untuk mata pelajaran Fisika berada dalam kategori sedang dan rendah. Jika dilihat dari aspek ARCS yang digunakan untuk mengukur motivasi belajar, maka urutan aspek tersebut dari persentase tertinggi yaitu satisfaction, attention, relevance, dan confidence. Ratarata motivasi belajar siswa berada dalam kategori sedang dan rendah disebabkan oleh kurang adanya ketertarikan dalam diri siswa untuk belajar Fisika. Selain itu, faktor luar yang mempengaruhi adalah lingkungan belajar siswa. lingkungan belajar yang aktif dapat menumbuhkan motivasi belajar. Lingkungan belajar aktif dapat diciptakan oleh guru melalui implementasi metode atau model pembelajaran yang aktif, kreatif, dan menyenangkan bagi siswa.

\section{Saran}

Mata pelajaran Fisika dipandang sebagai salah satu mata pelajaran yang sulit. Fisika merupakan kelompok mata pelajaran sains yang sarat dengan kegiatan eksperimen untuk membuktikan suatu konsep. Oleh karena itu, kurikulum untuk mata pelajaran sains sebaiknya: 1) mengarahkan guru dan siswa menuju proses penyelidikan (inkuiri) untuk menunjang kinerja siswa dalam belajar sains; dan 2) dirancang dengan memuat kegiatan eksperimen atau observasi yang menyenangkan bagi siswa. Bagi Guru Fisika, motivasi belajar merupakan pendorong pertama yang akan menggerakkan siswa untuk belajar lebih keras dan kemauan siswa mencari informasi yang lebih dalam tentang Fisika. Persentase motivasi belajar Fisika hasil penelitian ini untuk memberikan masukan kepada guru agar memahami tingkat motivasi siswa khususnya untuk pelajaran Fisika. Guru sebagai fasilitator harus mampu membangkitkan motivasi belajar siswa karena manfaat belajar sains yang di dalamnya juga mengkaji ilmu Fisika sangat penting untuk bekal siswa dalam kehidupan sehari-hari. Tingkat motivasi belajar yang dimiliki siswa berpengaruh terhadap prestasi belajar siswa. Oleh karena itu, siswa harus memiliki kesadaran dalam diri sendiri untuk belajar Fisika karena Fisika berkaitan langsung dengan fenomena dalam kehidupan sehari-hari. Selain itu, faktor lain yang dapat diterapkan untuk menumbuhkan motivasi belajar siswa adalah faktor model pembelajaran guru, media pembelajaran, lingkungan sekolah, dan kurikulum. Keberhasilan dalam mencapai suatu tujuan akan menghasilkan kepuasan dan siswa akan termotivasi untuk terus berusaha mencapai tujuan yang serupa. Untuk meningkatkan dan memelihara motivasi siswa, guru dapat menggunakan pemberian penguatan (reinforce- 
ment) berupa pujian, pemberian kesempatan dan sebagainya. Bagi peneliti lain, cara pengukuran tingkat motivasi belajar siswa dalam mata pelajaran menggunakan aspek ARCS (attention, relevance, confidence, satisfaction) sebagai dasar pengukurannya. Peneliti lain dapat menggunakan aspek-aspek motivasi belajar lain yang tentunya dapat diamati melalui observasi untuk menilai motivasi belajar siswa. Pengembangan instrumen motivasi belajar siswa berupa angket dan lembar observasi. Lembar observasi dapat pula dikembangkan dengan pemberian penilaian siswa tidak secara kualitatif, tetapi secara kuantitatif agar hasilnya dapat dibandingkan dengan skor angket.

\section{PUSTAKA ACUAN}

Arikunto, S. (2008). Prosedur penelitian (Edisi Revisi). Jakarta: Rineka Cipta.

Berlian, N. (2011). Faktor-faktor yang terkait dengan rendahnya pencapaian wajib belajar pendidikan dasar 9 tahun. Jurnal Pendidikan dan Kebudayaan, 17(1), 43-55.

Bloom, B.S., Engelhart, M.D., Furts, E.J., Hill, W.H., \& Krathwohl, D.R. (1956). Taxonomy of educational objectives, the classification of educational goals, handbook I: Cognitive domain. New York: Longman, Inc.

Budiawan, M., \& Arsani, N.L. (2013). Pengaruh model pembelajaran kooperatif tipe jigsaw dan motivasi belajar terhadap prestasi belajar ilmu fisiologi olahraga. Jurnal Pendidikan Indonesia, 2(1), 138-144.

Busato, V.V., Prins, F.J., Elshout, J.J., \& Hamaker, C. (2000). Intellectual ability, learning style, personality, achievement motivation and academic success of psychology students in higher education. Personality and Individual Differencess, 29(6), 1057-1068.

Christophel, D. M. (1990). The relationship among teacher immediacy behaviors, student motivation, and learning. Communication Education, 39(1), 1058-1075.

Cicuto, C.A.T., \& Torres, B.B. (2016). Implementing an active learning environment to influence students' motivation in biochemistry. Journal of Chemical Education, 93(6), 1020-1026.

Glynn, S.M., Brickman, P., Armstrong, N., \& Taasoobshirazi. (2011). Science motivation questionnaire II: Validation with science majors and nonscience major. Journal of Research in Science Teaching, 48(10), 1159-1176.

Hynd, C., Holschuh, J., \& Nist, S. (2000). Learning complex scientific information: Motivation theory and its relation to student perceptions. Reading and Writing Quarterly, 16(1), 2357.

Indah, D.S, Sunarno, W., \& Sarwanto. (2016). Pengembangan modul fisika berbasis SAVI (somatic, auditory, visualization, intellectually) untuk meningkatkan motivasi siswa pada pembelajaran fisika kelas $X$ SMK jurusan multimedia dengan topik impuls dan momentum. Jurnal Inkuiri, 20(2), 1-7.

Keller, J. M. (1987). Development and use of the ARCS model of instructional design. Journal of Instructional Development, 10(3), 2-10.

Meir, D. (2002). The accelerated learning hand book, panduan kreatif merancang program pendidikan. Bandung: Kaifa.

Piraksa, C., Srisawasdi, N. (2014). Promoting student's physics motivation by blended combination of physical and virtual laboratory environment: A result on different levels of 
inquiry. Proceeding of the $22^{\text {nd }}$ international conference on computers in education, 340348. Jepang: Asia-Pasific Society for Computers in Education.

Rahman, N.A. (2004). Efektivitas penggunaan metode inteligensi ganda dalam proses pembelajaran fisika di SMU. Jurnal Penelitian dan Evaluasi Pendidikan, 6(1),72-87.

Samsudin, A., Suhendi, E., Efendi, R., \& Suhandi, A. (2012). Pengembangan "CELS" dalam eksperimen fisika dasar untuk mengembangkan performance skills dan meningkatkan motivasi belajar mahasiswa. Jurnal Pendidikan Fisika Indonesia, 8(2012),15-25.

Sari, N. (2015). Pengaruh pembelajaran kooperatif model STAD dan think pair share terhadap kemampuan kognitif ditinjau dari motivasi siswa kelas X SMAN 6 Surakarta. Skripsi. Surakarta: Universitas Sebelas Maret.

Sirhan, G. (2007). Learning difficulties in chemistry: an overview. Journal of Turkish Science Education, 26(6),883-897.

Sudijono, A. (2010). Pengantar statistik pendidikan. Jakarta: Raja Grafindo Persada.

Sugiyono. (2012). Metode penelitian kualitatif, kuantitatif, dan R\&D. Bandung: Alfabeta.

Suparwoto. (2007). Dasar-dasar dan proses pembelajaran fisika. Yogyakarta: Fakultas MIPA UNY.

Uno, H. B. (2008). Teori motivasi \& pengukurannya. Jakarta: Bumi Aksara.

Velayutham, S., Aldridge, J., \& Fraser, B. (2011). Development and validation of an instrument to measure students' motivation and self regulation in science learning. International Journal of Science Education, 33(15),2159-2179.

Wang, P.H., Wu, P.L., Yu, K.W., \& Lin, Y.X. (2015). Infuence of implementing inquiry-based instruction on science learning motivation and interest: A perspective of comparison. Social and Behavioral Science, 174(2015),1292-1299.

Wenning, C.J. (2005). Levels of inquiry: Hierarchies of pedagogical practices and inquiry process. Journal of Physics Teacher Education Online, 2(3),3-11.

William, C. (2003). Why aren't secondary students interest in physics. Journal of Physics Education, 38(4),324-329. 